\title{
Risk Factor Assessment, Sero-Prevalence, and Genotyping of the Virus That Causes Foot-and-Mouth Disease on Commercial Farms in Ethiopia from October 2018 to February 2020
}

\author{
Fanos Tadesse Woldemariyam 1,2,3, Annebel De Vleeschauwer ${ }^{4}$, Nato Hundessa ${ }^{3}$, Ayelech Muluneh ${ }^{3}$, \\ Daniel Gizaw $^{3}$, Susanne Tinel ${ }^{1}$, Kris De Clercq ${ }^{4}$ (D) David Lefebvre ${ }^{4}$ and Jan Paeshuyse ${ }^{1, *(D)}$
}

check for updates

Citation: Woldemariyam, F.T.; De Vleeschauwer, A.; Hundessa, N.; Muluneh, A.; Gizaw, D.; Tinel, S.; De Clercq, K.; Lefebvre, D.; Paeshuyse, J. Risk Factor Assessment,

Sero-Prevalence, and Genotyping of the Virus That Causes

Foot-and-Mouth Disease on

Commercial Farms in Ethiopia from

October 2018 to February 2020.

Agriculture 2022, 12, 49. https://

doi.org/10.3390/agriculture12010049

Academic Editor: Nicole Kemper

Received: 14 November 2021

Accepted: 24 December 2021

Published: 31 December 2021

Publisher's Note: MDPI stays neutral with regard to jurisdictional claims in published maps and institutional affiliations.

Copyright: (C) 2021 by the authors. Licensee MDPI, Basel, Switzerland. This article is an open access article distributed under the terms and conditions of the Creative Commons Attribution (CC BY) license (https:// creativecommons.org/licenses/by/ $4.0 /)$.
1 Laboratory of Host Pathogen Interaction, Department of Biosystems, Division of Animal and Human Health Engineering, KU Leuven, 3000 Leuven, Belgium; fanostadesse.woldemariyam@kuleuven.be (F.T.W.); susanne.tinel@outlook.be (S.T.)

2 College of Veterinary Medicine, Addis Ababa University, Addis Ababa P.O. Box 34, Ethiopia

3 National Animal Health Diagnostic and Investigation Center, Sebeta P.O. Box 04, Ethiopia; natohunde@gamil.com (N.H.); ayu.muluneh@yahoo.com (A.M.); nebiyudan@gmail.com (D.G.)

4 Sciensano, Service for Exotic Viruses and Particular Diseases, 1180 Brussels, Belgium; Annebel.DeVleeschauwer@UGent.be (A.D.V.); kris.declercq@sciensano.be (K.D.C.); david.lefebvre@sciensano.be (D.L.)

* Correspondence: jan.paeshuyse@kuleuven.be

\begin{abstract}
A cross-sectional serological, active outbreak search and a questionnaire-based survey were carried out to investigate foot-and-mouth disease (FMD) sero-epidemiology in Ethiopia. The circulating serotype of the FMD virus (FMDV) was identified, and the knowledge regarding FMD and husbandry practices was assessed. Using the questionnaire survey, a total of 237 individuals were interviewed, and the majority responded that there is no practice of reporting disease outbreak, free in and out movement of livestock, or share pastures, and they use traditional case management as a means of controlling the disease. A total of 1938 cattle, 490 domestic small ruminants, and 426 swine were sampled randomly for serological analysis using the $3 \mathrm{ABC}$ non-structural protein (NSP) enzymelinked immunosorbant assay. An overall prevalence of $25 \%$ in cattle, $5 \%$ in domestic small ruminants, and $2 \%$ in swine was recorded. Multivariable logistic regression analysis revealed that cattle from the Oromia, Tigray, and Amhara regions had the highest probability of being sero-positive as compared with Addis Ababa odds ratio(OR)(OR: 4 (95\% confidence interval (CI)(CI [3-6], 3 (95\% CI [2,5]), and 2 (95\% CI 2 [1,3]), respectively)). Older cattle (older than three years) and domestic small ruminants ( $>18$ months) had a higher chance of being seropositive (OR: 2, 95\% CI [1.6,3]) and (OR: 6, 95\% CI $[2,18])$, respectively). Female and older swine older than three years of age had a higher chance of being sero-positive $(p<0.05)$. Local breed cattle had the lowest chance (OR: 0.2. 95\% CI [0.1-0.3]) of being sero-positive. A region, age, and breed proved to have a statistically significant association with sero-positivity $(p<0.05)$ in cattle. Swine from Bishoftu were less likely to test positive than swine from Addis Ababa (OR: 0.04, 95\% CI [0.01-0.3]). From 96 herds, 72 pooled outbreak samples were analyzed by polymerase chain reaction (PCR), virus isolation, serotyping (antigen enzyme linked immunosorbant assay (ELISA)), sequencing, and phylogenetic tree analysis. Six serotype A (G-IV) FMD viruses and three serotype O east African (EA-3 and EA-4) FMDVs were identified. Thus, this study established the lack of disease outbreak reporting, poor husbandry problems, and the prevalence of FMD in three domestic species (cattle, small ruminant, and swine). In addition, continuous circulation of serotype $\mathrm{A}$ and $\mathrm{O}$ in the study area was confirmed.
\end{abstract}

Keywords: Ethiopia; FMDV; molecular characterization; outbreak; swine; risk factors; sero-pevalence; small ruminants; serotype 


\section{Introduction}

Foot-and-mouth disease is a highly contagious, debilitating (adult), highly mortal (newborn calves), and economically important vesicular viral transboundary animal disease affecting wild and domestic cloven-hoofed animals [1-3]. The disease is caused by the foot-and-mouth disease virus (FMDV), a positive-sense single-stranded RNA virus of the genus Aphthovirus of the family Picornaviridae [4]. It is an antigenically variable virus with varying distributions in large areas of predominantly Africa and Asia. There are seven known serotypes (O, A, C, Asia1, SAT-1, SAT-2, and SAT-3). Serotypes O, A, SAT-1, and SAT-2 are in circulation in most of the sub-Saharan African countries from East, Central, and West Africa. There is no universal vaccine that can confer protection against all serotypes and subtypes $[5,6]$.

Foot-and-mouth disease has been ranked among the top five economically important endemic viral diseases in cattle in Ethiopia since it was first reported in $1957[7,8]$. This disease is known to cause several outbreaks each year [9]. Studies from different corners of the country have reported a seroprevalence of 9 to $26 \%$ in cattle $[8,10-14]$, and recently, seroprevalence rates of $24 \%$ [14] and $15 \%$ [15] in central Ethiopia and the Amhara regional state, respectively, were reported. A seroprevalence of 4 to 11\% [15-17] was reported in small ruminants. Furthermore, a seroprevalence of $30 \%$ was reported in ungulate wild mammals [16]. A recent report from dairy farms of central Ethiopia indicated a seroprevalence of $72.1 \%$ [18]. In Ethiopia, outbreak investigation studies indicated that FMD occurs year-round in most parts of the country. Several outbreak studies showed that four of the seven serotypes $(\mathrm{O}$, A, SAT- 1 , and SAT-2) were reported in the country in the order of the dominancy of their occurrence and the economic loss they incur $[19,20]$. The continuous occurrence of serotype $\mathrm{O}, \mathrm{A}$, and SAT- 2 was confirmed by recent retrospective studies of Gizaw et al. [21] and Tesfaye et al. [22]. Serotype $\mathrm{O}$ and A were reported in all parts of Ethiopia as well as SAT- 1 and SAT-2 in the central and southern half of the country, where $70 \%$ of the country's cattle population is found. The livestock production system practiced in Ethiopia that mainly involves dairy cattle are performed in a commercial or mixed crop-livestock, pastoral oragro-pastoral setting. Where as in beef production commercial feedlots, small-scales, mixed crop-livestock, pastoral or agro-pastoral production systems are practiced [23]. These production systems in Ethiopia, that is, the mixed crop-livestock, pastoral and agro-pastoral, and the market-oriented production system (commercial), comprise $80-85 \%, 50-60 \%$, and $1 \%$ (the growing), respectively, of the cattle population [24]. In the Ethiopian context, no organized control practices and risk mitigation strategies have been put in place in any of the production systems $[11,17,25]$. Though the disease is endemic, with adequate epidemiological understanding encompassing the majority of the regions, the domestic susceptible species in the commercial setting are very limited. Seroprevalence studies, identification of risk factors, and effective outbreak investigation are crucial for an appropriate control approach. Thus, this study aimed at investigating the sero-epidemiology; knowledge, practice, and attitude of livestock owners and veterinary professionals, as well as agent characterization from the outbreak area in Ethiopia. The specific objectives were to estimate the seroprevalence of FMD in selected commercial farms of cattle, small ruminants, and swine; to assess the knowledge, practice, and attitude of livestock owners and veterinary professionals about FMD potential risks; and to determine the control options and characterization of the FMDV field isolates at a molecular level from active outbreaks.

\section{Materials and Methods}

\subsection{Study Areas}

The study was conducted in four regional states (Oromia, Amhara, Tigray, and South Nation Nationality People (SNNP) and one city administration (Addis Ababa) of Ethiopia (Figure 1). These regions were selected because of the presence of a high number of animals per $\mathrm{km}^{2}$, ranging from 29 to 70,71 to 101,102 to 145 , and 145 to 1136 as the first, median, third, and maximum quartile values ( high densities) of livestock, respectively, 
in the remaining part of the country [26]. The country is divided into nine administrative regions. Ethiopia is landlocked and found in the horn of Africa. It is geographically located between $32^{\circ} 30^{\prime}-48^{\circ} 00^{\prime} \mathrm{E}$ and $3^{\circ} 00^{\prime}-15^{\circ} 00^{\prime} \mathrm{N}$. Agro-ecologically, the country is divided into different areas: a low land area below 1500 masl, with an average temperature of $27^{\circ} \mathrm{C}$ and $510 \mathrm{~mm}$ annual rainfall; a mid-land area at an altitude of 1500 masl to 2300 masl, with an average temperature of $22{ }^{\circ} \mathrm{C}$ and $510-1530 \mathrm{~mm}$ annual rainfall; and highlands, at an altitude above 2300, with an average temperature of $16{ }^{\circ} \mathrm{C}$ and 1530-2000 $\mathrm{mm}$ annual rainfall. The study areas encompass all the mentioned agroecology from low land to high land, though the study area is dominated by mid land and high land agroecology. The livestock production system in the region is dominantly a subsistence crop-livestock mixed system [27]. In this study, all of the production systems (intensive, semi-intensive, and extensive systems) were included. Ethiopia has a ruminant population of 60.39 million cattle, 31.30 million sheep, and 32.74 million goats. The swine population in Ethiopia is estimated to be 28,696 , which are only reared in a commercial setting to supply the Chinese community and some expatriates of other countries with pork meat [28]. The different livestock production systems practiced in Ethiopia are as follows: commercial/market-oriented urban/peri-urban, mixed crop-livestock, and the pastoral/agro-pastoral livestock husbandry practices in dairy, whereas in beef (feedlots), small-scale, mixed crop-livestock, and pastoral/agro-pastoral systems with extensive and semi-intensive production are practiced.

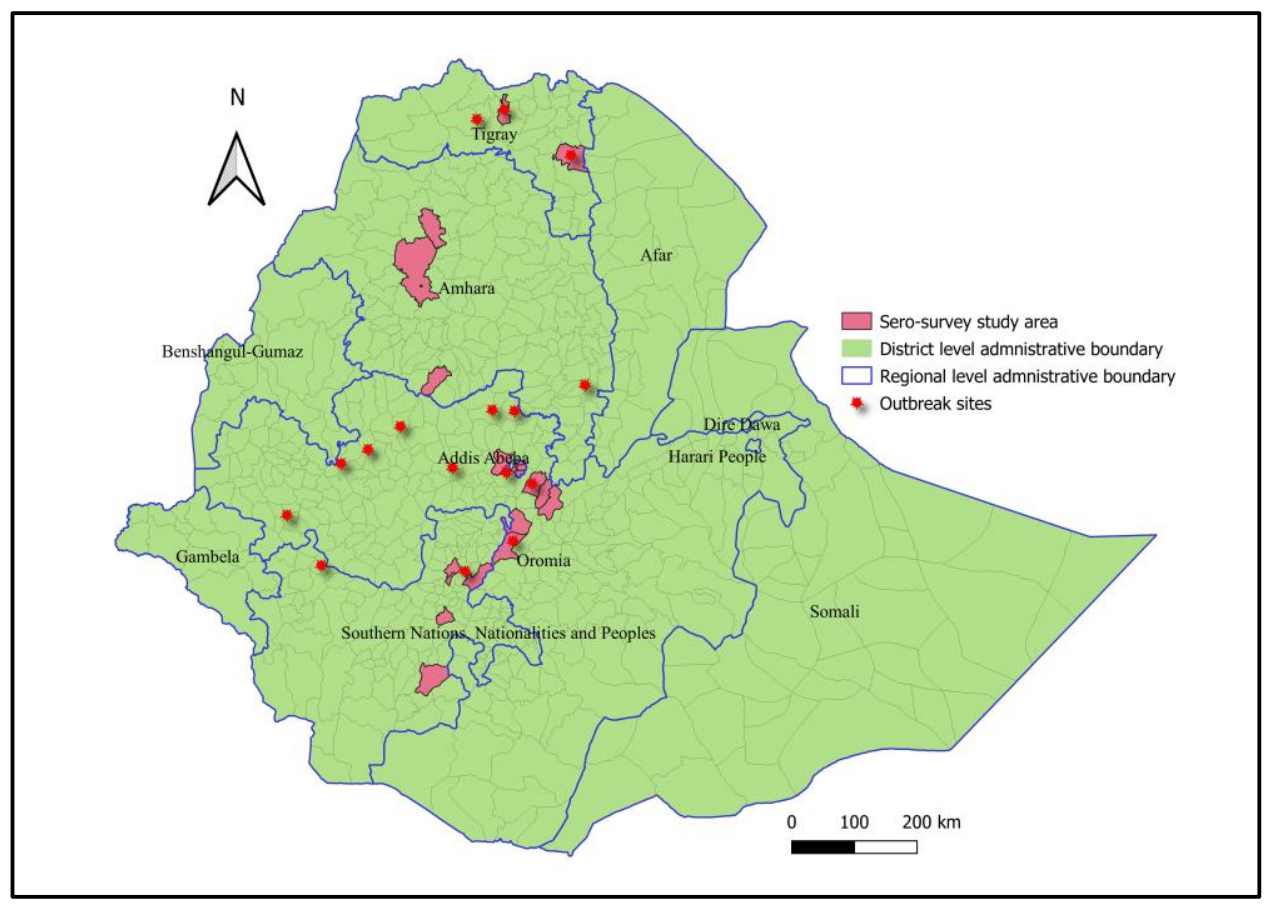

Figure 1. Map of study areas for the FMD outbreak investigation and sero-survey in cattle.

\subsection{Study Population, Sampling Strategy, and Sample Size Determination}

A cross-sectional survey design with a multi-stage (six stages) cluster sampling technique was used. A risk factor assessment along with a semi-structured questionnaire, a seroprevalence study, and a report-based outbreak investigation was performed.

The following units were selected for multi-stage (six stages) sampling in the serosurvey and risk factor assessment as a cluster unit. Regional states were selected purposively as the first unit, zones (administrative hierarchy between region and districts) as the second, districts as the third, peasants' associations/periurban communes as the fourth, and herds/commercial farms and individual animals as biological units. As a cluster, regions, zones, districts, peasant associations, and farms were selected purposively. 
Specific peasant associations and commercial farms were selected based on their accessibility and convenience (availability). For the seroprevalence study, each animal was randomly selected. Strict random sampling was influenced by the owners' willingness, the physiological status of the animal, and the production system in the study area. During blood collection, animals were selected for sampling regardless of their sex, breed, or body condition, and production type.

The questionnaire was prepared after a literature review of a various studies conducted to identify risk factors associated with FMD elsewhere in the world [20,29,30]. A questionnaire pretested on ten respondents in a pilot study was used to retrieve information about the risk factor of FMD in a specific area. The questionnaire was distributed in all regions included in the seroprevalence study. To this end, 47 (37 farmers and 10 veterinarians) respondents per region were selected randomly and asked for their willingness to complete the questionnaire. Out of 237 respondents 185 were farmers, and 52 were veterinarians, all from five regions. The sampling of the farmers and the veterinarian was done parallel to the sero-survey and outbreak investigation. The questionnaire given to the farmer was exactly the same as presented to the veterinarians.A brief introduction of the aim of the study and an explanation of each question were given. This included instructions on how to fill the questionnaire and clarification of specific question when requested. The participants' oral consent was obtained after they were told about the confidentiality of their responses.

For the outbreak investigation, thorough physical examinations were conducted on clinically sick animals and clinical signs were record. Animals were considered positive for FMD based on clinical definition such as high body temperature, excessive salivation, vesicle, and erosion on the tongue, nose, lip, and oral mucosa plus inter-digital space and coronary bands on the feet. In addition to these parameters, reduced appetite, depression, fever, hyper-salivation, and lameness were also evaluated The outbreak sampling was purely purposive sampling when animals showing all clinical signs mentioned above [31-33]. Sample size determination was done by the formula for the estimation of prevalence using random sampling as provided in [34,35]. This was done by substituting the expected prevalence of $14.5 \%$ for cattle [9] and 50\% for domestic small ruminants (no or limited representative study in Ethiopia) and swine (considering no or limited study in Ethiopia). A 95\% level of confidence and a 5\% desired level of precision were used to calculatea minimum sample size. Thus, 191 cattle, 384 domestic small ruminants, and 384 swine were calculated to be sampled for this study.

$$
\mathrm{n}=\frac{1.96^{\wedge} 2 * P \exp *(1-P \exp )}{d^{\wedge} 2}
$$

where $\mathrm{n}=$ required sample size, $d=$ desired level of precision, and Pexp $=$ expected prevalence. The above sample size was adjusted by multiplying the design effect by five for the cluster sampling method employed in cattle. By doing so the sample size for cattle was calculated to be 955 animals but we collected 1938 samples in total. For Since 50\% prevalence was taken as a minimum domestic small ruminants and swine, a minimum of 384 animals were sampled for each species. For cattle, the targeted sample size was 955 animals, which translated in 191 from 10 peasant associations for each region. In total, 40 peasant associations and 10 periurban communes (in Addis Ababa) were included. During sampling, a minimum of 20 samples from each peasant association were collected. In addition, based on the livestock population, availability of commercial farms, and accessibility, the sample size was increased. Which in turn increases the precession of the study results. This resulted, for cattle 532 animals sampled in Oromia 435 animals in Amhara, 385 animals in Tigray, 300 animals in Addis Ababa, and 285 animals in South Nation Nationality People (SNNP) Small ruminants were sampled at the abattoir taking in consideration the origin of the animals. Similarly for swine representative samples from accessible animals in the farms located in the areas studied were sampled. 


\subsection{Sample and Data Collection \\ Serum Sample Collection}

Blood samples were collected from the jugular vein of individual animals, using sterile plain vacutainer tubes. About six milliliters of blood was withdrawn from each animal. The samples were coded, stored overnight in an inclined position at room temperature for serum separation. The serum was transferred into sterile cryovials after separation. The sera samples were stored at $-20^{\circ} \mathrm{C}$ at a nearby regional laboratory until the sampling of that area was finished. Samples were transported to the National Animal Health Diagnostic Investigation Center (NAHDIC, Ethiopia) stored in an ice box with ice packs. Next, samples were submitted to NAHDIC through the sample reception desk.

\subsection{Serum and Outbreak Sample Collection}

For each sampled animal, breed, age, sex, and husbandry data were collected. Among husbandry data production systems, history of vaccination and history of contact with wildlife were collected to assess their association with FMD sero-positivity. The breed of animal was categorized as cross and local. Age was categorized as young (6 months to 3 years of age for cattle, 6 months to $<18$ months of age for small ruminants, adults $>3$ years of age for cattle, and $>18$ months for small ruminants). Swine were classified as young ( $>6$ months to 1 year) and adult ( $>1$ year) [36]. The production system was categorized as extensive livestock production systems (free grazing), intensive livestock production systems (restricted livestock movement, vehicles, and authorized personnel), and semiintensive livestock production systems (movement of livestock was less controlled). The vaccination status and contact with wildlife were recorded as "yes" or "no".

For outbreak sampling, once key informants from the district's veterinary office reported the outbreak sample collection was done after the animals were thoroughly examined for the presence of FMD clinical symptoms (see Section 2.2). From clinically FMD-suspected cattle, sufficient epithelial tissues and oral swabs from oral lesion were collected. These samples were then placed in sterile screw capped test tubes containing transport medium composed of equal amounts of glycerol and $0.04 \mathrm{M}$ phosphate buffer, pH 7.2-7.6, with added antibiotics (penicillin, neomycin sulphate, polymyxin B-sulphate or Mycostatin). Then labeled, kept in an ice box, transported and submitted to NAHDIC virology laboratory. Sampling was done following procedures described by.

\subsection{Questionnaire Survey}

A semi-structured questionnaire (provided as a supplemental file) was prepared to assess the knowledge, attitude, and practice of the respondents. The questions included herd information, production system, previous/recent FMD outbreak, livestock movement, grazing system, contact with wildlife, contacts at watering point, animal purchases from the markets, report of outbreak situations, and control options that are practiced. A total of 237 questionnaires were completed, 185 farmers from five regions. In each region, a minimum of 37 questionnaires completed. Additionally, 52 veterinarians completed a questionnaire. For each region a minimum of 10 respondents per region completed the questionnaire. The participants' oral consent was obtained after they were told about the confidentiality of their response.

\section{Laboratory Analysis}

\subsection{Serological Analysis}

Serum samples were screened for antibodies against the highly conserved NSP of the FMDV using FMD non-structural protein ELISA (3ABC-ELISA) to identify FMD seropositive and negative animals. A commercially available test kit (PrioCHECK ${ }^{\circledR}$ FMDV NSP, Thermo Fisher Scientific, The Netherlands) was used. Test plates of the kit contained FMDV NSP captured by the coated $3 \mathrm{ABC}$ specific $\mathrm{mAb}$. This test can identify antibodies of natural infection from vaccination. The assay was performed according to the manufacturer's 
instructions [37]. The results were analyzed and interpreted using the percentage inhibition (PI) value of each sample calculated.

\subsection{Molecular Analysis}

An epithelial tissue suspension was prepared by grinding the sample in using a sterile pestle and mortar sterile sand added. The suspension was centrifuged at $3000 \mathrm{rpm}$ for $10 \mathrm{~min}$, and the supernatant was taken for the molecular analysis. Total viral RNA was extracted from the digested tissue supernatants and oral swab sample using the QIAamp ${ }^{\circledR}$ Viral RNA extraction kit (Qiagen Inc., Hilden, Germany) following the mini NucleoSpin column protocol according to the manufacturer's instructions. The presence of viral RNA was determined by using one-step real-time RT-PCR (rRT-PCR) targeting the FMDV 3D region as adapted from Reid et al., [38] and implemented and validated at NAHDIC. The results were interpreted as follows: samples with $\mathrm{Ct}<32$ were classified as positive, samples with 32 to 50 were ambiguous and marked for re-testing, and samples with no $\mathrm{Ct}$ (undetected) were classified as negative. The cycle threshold value (Ct value) was set automatically by the pre-loaded machine software. Selected FMDV positive samples were further analyzed for virus isolation, serotyping at NAHDIC, and VP1 sequencing at the World Reference Laboratory (WRL) for FMD, Pirbright, United Kingdom (UK).

The detection and typing of FMD viruses from epithelial tissue suspensions were done using the IZSLER ${ }^{\circledR}$ (Brescia, Italy) antigen-capturing ELISA test kit. The assay is an indirect sandwich ELISA that has selected combinations of anti-FMDV monoclonal antibodies (mAbs), used as coated and conjugated antibodies. The assay was performed, and the results were interpreted as per the manufacturer's instructions.

Selected epithelial tissue suspensions were shipped on dry ice to WRL for FMD, Pirbright, UK, for further sequencing using the Sanger sequencing. Nine VP1 sequences, i.e., six serotype A and three serotype O FMD viruses, were obtained. One sequence from each FMD serotype virus was used for an online basic nucleotide alignment search tool (BLAST) search to retrieve closely related sequences from GenBank using Molecular Evolutionary Genetics Analysis software (MEGA, V 6.0) [39]. The VP1 nucleotide sequences were aligned by using the ClustalW algorithm program embedded in MEGA software. The aligned sequences were used to construct phylogenetic trees using the midpoint-rooted neighborjoining tree and Kimura 2-parameter nucleotide substitution model construct distance matrices by using the program MEGA 6.0. Midpoint-rooted neighbor-joining trees were then constructed. The robustness of the tree topology was assessed with 1000 bootstrap replicates as implemented in the program [39].

\subsection{Data Analysis}

A Microsoft Excel (version:14.0.4734.1000, Microsoft, Albuquerque, NM, USA) spreadsheet was used to record and code the data generated from laboratory investigation and questionnaire assessment and analyzed using STATA version 14 [40]. Seroprevalence and knowledge, attitude, and practice (KAP) study information was analyzed by descriptive statistics.

The seroprevalences was calculated as a proportion of seropositive to the total number of animals tested, and $95 \%$ confidence intervals were given for the estimates. The true prevalence $(T P)$ was derived from the apparent prevalence $(A P)$ based on the sensitivity $(S e)$ and specificity $(S p)$ of the diagnostic test as described by [34].

$$
T P=\frac{A P+S p-1}{S e+S p-1}
$$

In this case, the test specificity and sensitivity for PrioCHECK FMDV NSP ELISA were 95 and 98\%, respectively (https:/ / assets.thermofisher.com, accessed on 12 June 2021). Multivariable logistic regression and odds ratio were employed to identify factors associated with the FMD sero-positivity. Here, sero-positivity status was the dependent variable and FMD risk factors were the predictor variables. Separate analyses were performed for cattle, 
swine, and small ruminants. Here, the cattle odds ratio was used to measure the degree of association between regions, age, breed, production type, vaccination status, and contact of wild animals with sero-positivity. Similarly, in domestic small ruminants, the odds ratio was used to determine the degree of association between the origin, age, and species of animals with sero-positivity. In swine, the degree of association between age, breed, and origin with sero-positivity was evaluated. In all statistics, the confidence level was held at $95 \%$, and $p<0.05$ was set for statistical significance. To map the geographic distribution of the disease (outbreak) and serum sampling in the study area, QGIS version 2.18 GIS software was used [41].

\section{Results}

\subsection{Knowledge of FMD Occurrence, Introduction, and Control Practices}

A semi-structured questionnaire was filled out by 237 individuals (185 farmers and 52 veterinarians) who were directly involved in livestock farming. From these participants, $54 \%$ of the farmers and $67 \%$ of the veterinarians responded that once the outbreak of FMD occurred on their farm, they reported it to the responsible body. About $56 \%$ practiced free movement (free grazing where animals are allowed to mix with different herds during grazing and at watering points) in their livestock production, whereas $33 \%$ and $11 \%$ of them followed semi-restricted (movement of livestock was less controlled) and restricted (restricted livestock movement, vehicles, and authorized personnel) livestock production systems. Eighty-one, 61, 64, and 63\% of the respondents had the experience of sharing pasture with swine, domestic small ruminants, different peasant associations, and wildlife, respectively. On the farm, 75 and $73 \%$ of the respondents replied that animals and vehicle and personnel's movement in and out was allowed (Table 1).

Table 1. Frequency of respondents with different risk factors to FMD occurrence (2018 to 2020) $(N=237)$.

\begin{tabular}{|c|c|c|c|}
\hline 1. Type of Movement & & Frequency & Percentage \\
\hline 1.1. & Free & 133 & 56 \\
\hline 1.2 . & Semi restricted & 78 & 33 \\
\hline 1.3. & Restricted & 26 & 11 \\
\hline \multicolumn{4}{|c|}{ 2. Share Pasture with Swine } \\
\hline 2.1 . & yes & 192 & 81 \\
\hline 2.2 . & no & 45 & 19 \\
\hline \multicolumn{4}{|c|}{ 3. Share Pasture with Domestic Small Ruminants } \\
\hline 3.1 & yes & 152 & 64 \\
\hline 3.2 . & no & 85 & 36 \\
\hline \multicolumn{4}{|c|}{ 4. Share Pasture with Different Peasant Association } \\
\hline 4.1. & yes & 144 & 61 \\
\hline 4.2 . & no & 93 & 36 \\
\hline \multicolumn{4}{|c|}{ 5. Share Pasture with Wildlife } \\
\hline 5.1. & yes & 150 & 63 \\
\hline 5.2 . & no & 87 & 37 \\
\hline \multicolumn{4}{|c|}{ 6. Animal Movement in and out of the Farm } \\
\hline 6.1. & yes & 178 & 75 \\
\hline 6.2 . & no & 59 & 25 \\
\hline \multicolumn{4}{|c|}{ 7. Movement of Vehicle and Workers in and out } \\
\hline 7.1. & yes & 174 & 73 \\
\hline 7.2 . & no & 63 & 27 \\
\hline
\end{tabular}


The majority of the respondents believed that the main source of FMD outbreak was communal grazing, sharing watering points, and unrestricted movement of animals, personnel's and vehicles in and out. According to the questionnaire survey, $25 \%$ of the respondents had encountered FMD vaccine failure in their production system. The majority of vaccinating personnel (53\%) were government-employed veterinarians followed by private veterinarians ( $45 \%$ ). Only $2 \%$ of the respondents administered the vaccination on their own at the farm level (Table 2). FMD outbreaks have been witnessed by $68 \%$ of all (farmers and veterinarians) respondents. Of the respondents that witnessed FMD outbreaks $69 \%$ of them had one outbreak in a year. The rest experienced two (16\%), three $(6 \%)$, and four (9\%) outbreaks per year. Accordingly, 67\% of respondents, reported no deaths of animals during the outbreak. In addition, though $65 \%$ of the outbreaks were reported to the responsible authority, only a $26 \%$ response rate was seen for sampling from veterinary officials. According to the respondents, $69 \%$ of the farmers and $42 \%$ veterinarians replied that they follow and treat their animals on a case by case basis to reduce the spread of the disease. Movement restriction was practiced by $2 \%$ of the farmers and $15 \%$ of the veterinarians as a means to control and prevent disease incidence and/or spread. But $3 \%$ of farmers use no intervention to control the disease. From the total respondents 48 farmers and 15 veterinarians use vaccination and case management as a control strategy. Out of the total 63 respondents that use vaccination 59 of them experienced vaccine failure (Tables 2 and 3).

Table 2. FMD vaccine failure (recurrent outbreak after vaccination) and vaccinating personnel's frequency from 2018 to $2020(N=237)$.

\begin{tabular}{ccc}
\hline Vaccinating Personnel & Frequency & Percentage \\
\hline Private & 106 & 45 \\
Government & 126 & 53 \\
Own & 5 & 2 \\
\hline Yes & Vaccine Failure & 25 \\
No & 59 & 75 \\
\hline
\end{tabular}

Table 3. Occupation of the respondents and their control strategy applied (2018 to 2020) $(N=237)$.

\begin{tabular}{cccccc}
\hline \multicolumn{5}{c}{ Control Strategy Practiced Once the Outbreak Occurred } \\
\hline $\begin{array}{c}\text { Occupation } \\
\text { of the } \\
\text { Respondents }\end{array}$ & Vaccination & Treatment & $\begin{array}{c}\text { Movement } \\
\text { Restriction }\end{array}$ & $\begin{array}{c}\text { All Together } \\
*\end{array}$ & None \\
\hline $\begin{array}{c}\text { Farmer } \\
\text { Veterinarian }\end{array}$ & $48(26 \%)$ & $128(69 \%)$ & $4(2 \%)$ & $0(0.0 \%)$ & $5(3 \%)$ \\
Total & $63(27 \%)$ & $150(63 \%)$ & $12(5 \%)$ & $7(13 \%)$ & $0(00 \%)$ \\
\hline
\end{tabular}

* All together: use of all control strategies together (vaccination, treatment, and movement restriction).

\subsection{Sero-Prevalence of FMD in Cattle, Small Ruminants, and Swine}

In this study, an overall national seroprevalence of FMDV in cattle, small ruminants, and swine was recorded as 25,5, and 2\%, respectively. Different risk factors (region, age, breed, production type) associated with antibodies against FMDV NSP were assessed.

\subsubsection{Seroprevalence of FMD in Cattle}

During the study period, a total of 1938 cattle sera samples were collected from four regions and one city administration commercial farm. An overall apparent seroprevalence of $25 \%$ was recorded. The overall true prevalence adjusted for the sensitivity and specificity of the imperfect diagnostic test used was $21.5 \%$. 
The highest regional FMDV seroprevalence $(38.6 \%)$ was recorded in Tigray followed by Oromia (26.8\%), Amhara (23.9\%), Addis Ababa (17.7\%), and South Nation Nationality People (11.2\%) regional states. A seroprevalence of 26 and $23 \%$ was observed in female and male cattle, respectively. Similarly, amongst the age categories, adult animals ( $>3$ years) had the highest level of sero-positivity $(31.7 \%)$ for FMDV infection as compared to their younger counterparts (16.9\%). Based on breed-specific prevalence, cross-breeds showed the highest level of FMDV sero-positivity $(27.4 \%)$ in comparison to their local breed counterparts (18.4\%). Concerning contact with wild animals, though $22.5 \%$ sero-positivity was seen in animals that did not have contact with wild animals, $48.5 \%$ of the animals that had contact with wild animals were sero-positive. Unvaccinated animals were found to be $26 \%$ seropositive as compared to the vaccinated group with $19.2 \%$ sero-positivity. Concerning the production system, animals raised under extensive management systems were $31.7 \%$ seropositive followed by $25 \%$ and $23 \%$ semi intensively and intensively managed animals. Risk factors, such as age, region (agroecology) (SNNP), contact with wild animals, vaccination status, and production systems were statistically significantly associated with FMDV seropositivity in cattle $(p<0.05)$ (Table 4$)$. The likelihood of being sero-positive was assessed among regions and showed that cattle from the Oromia, Tigray, and Amhara regions had the highest chance of being sero-positive as compared to Addis Ababa ( ${ }^{*}$ reference category) with (OR: 4, 95\% CI [3,6]), (OR: 3, 95\% CI, [2,5]), and (OR:2, 95\% CI, [1,3]), respectively. The likelihood of FMDV sero-positivity was higher in old animals with (OR: 2, 95\% CI [1.6,3]) as compared to their younger counterparts. Local breeds had the lowest chance of being FMDV sero-positive as compared to cross-breed animals with an odds ratio of (OR: $0.2,95 \%$ CI $[0.2,0.3])$. Factors such as contact with wild animals, being unvaccinated, and managing under an extensive system resulted in a higher chance of being sero-positive as compared to animals that did not have contact with wild animals, vaccinated and intensively or semi-intensively managed animals, respectively (Table 4).

Table 4. Factors associated with FMD sero-positivity using multivariable logistic regression analysis in cattle (2018 to2020) $(N=1938)$. Risk factors and their association with seroprevalence.

\begin{tabular}{|c|c|c|c|c|c|c|}
\hline Risk Factors & & $\begin{array}{l}\text { Total Tested } \\
\text { Samples }\end{array}$ & Sero-Positive & Sero-Prevalence (\%) & $\begin{array}{l}\text { Odds Ratio } \\
\text { (95\% CI) }\end{array}$ & $p$-Value \\
\hline \multirow[t]{5}{*}{ Region } & Addis Ababa * & 300 & 53 & 17.7 & - & \\
\hline & Oromia & 532 & 143 & 26.8 & $4[3,6]$ & $<0.001$ \\
\hline & Amhara & 435 & 104 & 23.9 & $2[1,3]$ & $<0.001$ \\
\hline & Tigray & 386 & 149 & 38.6 & $3[2,5]$ & $<0.001$ \\
\hline & SNNP & 285 & 32 & 11.2 & $0.8[0.5,1]$ & 0.36 \\
\hline \multirow[t]{2}{*}{ Age group } & Young * & 900 & 152 & 16.9 & - & \\
\hline & Adult & 1038 & 329 & 31.7 & $2[1.6,3]$ & $<0.001$ \\
\hline \multirow[t]{2}{*}{ Breed } & Cross* & 1373 & 377 & 27.4 & & \\
\hline & Local & 565 & 104 & 18.4 & $0.2[0.2,0.3]$ & $<0.001$ \\
\hline \multirow{2}{*}{$\begin{array}{l}\text { Contact with } \\
\text { wild animals }\end{array}$} & No * & 1765 & 397 & 22.5 & - & \\
\hline & Yes & 173 & 84 & 48.5 & $5[5,8]$ & $<0.001$ \\
\hline \multirow[t]{2}{*}{ Vaccinated } & No* & 1599 & 416 & 26.0 & & \\
\hline & Yes & 339 & 65 & 19.2 & $2[1.1,3.3]$ & 0.001 \\
\hline \multirow[t]{3}{*}{ Production type } & Extensive* & 194 & 62 & 31.7 & - & \\
\hline & Intensive & 793 & 182 & 22.9 & $0.6[0.4,0.9]$ & 0.010 \\
\hline & Semi intensive & 951 & 237 & 24.9 & $0.7[0.5,1]$ & 0.043 \\
\hline
\end{tabular}

* reference category.

\subsubsection{Sero-Prevalence of FMD in Domestic Small Ruminants}

In this study, a total of 490 domestic small ruminants' serum was collected from export abattoir slaughtering of sheep and goats. The animals originated from different areas such 
as Abergele (Tigray), Arsi-Bale (East Oromia), Horo (west Oromia), Jima (West Oromia), Jinka (South Nation Nationalities People), Borena (south Oromia), and Somali regions. The overall apparent seroprevalence of the animals against FMDV NSP ELISA was 5\% $(n=490)$. The sero-positivity of the animals based on their origin showed that animals from Arsi-Bale had a $16.6 \%$ seroprevalence followed by animals from Borena (15.2\%). Agewise, the highest prevalence was recorded in adult animals with a seroprevalence of $8.6 \%$. Statistical inference was difficult, as the sample sizes between groups differ and are small. The chance of being sero-positive was higher in adult animals (>18 months) with OR: 6, $95 \%$ CI, $[2,18]$ as compared to their younger counterparts. Caprine species were seen to have 3.8\% sero-positivity, but the chance was eight times higher (OR: 8, 95\% CI, [3, 22]) for ovine as compared to caprine. Although statistical inference with this small sample size for ovine samples is difficult. Risk factors, such as the age group of animals, were statistically significantly associated with FMDV sero-positivity at $(p<0.05)$ (Table 5).

Table 5. Factors associated with FMD sero-positivity using multivariable logistic regression analysis in domestic small ruminants $(N=490)$.

\begin{tabular}{|c|c|c|c|c|c|c|}
\hline Risk Factors & & Tested & Sero-Positive & Sero-Prevalence $(\%)$ & Odds Ratio (95\% CI) & $p$-Value \\
\hline \multirow[t]{7}{*}{ Origin } & Abergale * & 38 & 0 & 0 & - & \\
\hline & Arsi-Bale & 72 & 12 & 16.6 & $3[1,10]$ & 0.038 \\
\hline & Horo & 99 & 0 & & - & \\
\hline & Jimma & 95 & 5 & 5.2 & - & \\
\hline & Jinka & 122 & 0 & & & \\
\hline & Borena & 33 & 5 & 15.2 & $3[1,11]$ & \\
\hline & Somali & 31 & 0 & 0 & - & \\
\hline \multirow[t]{2}{*}{ Age group } & Young * & 259 & 4 & 1.5 & - & \\
\hline & Adult & 231 & 20 & 8.6 & $6[2,18]$ & $<0.001$ \\
\hline \multirow[t]{2}{*}{ Species } & Caprine * & 465 & 18 & 3.8 & - & - \\
\hline & Ovine & 25 & 6 & 24 & $8[3,22]$ & $<0.001$ \\
\hline
\end{tabular}

\subsubsection{Sero-Prevalence of FMD in Swine}

Out of 426 swine sera samples, an overall apparent seroprevalence of $2 \%$ was identified to be positive for anti-FMDV NSP antibodies. The true prevalence was not adjusted here because the prevalence was less than 5\%. According to the result, it was indicated that an $8.6 \%$ prevalence was observed in Addis Ababa. Similarly, adult swine showed higher sero-positivity, 3.3\% for FMDV infection. It was also revealed that $1.8 \%$ seroprevalence was found in female swine. Additionally, the highest level of sero-positivity for FMDV was recorded in the Duroc breed (3\%) followed by crossbreeds $(2.8 \%)$ and swine of the large white breed (1.6\%) (Table 6). However, the variables under investigation (age, sex, and breed) were not significant predictors of FMDV sero-positivity in swine $(p>0.05)$.

\subsection{Molecular Detection and Characterization of FMDV}

\subsubsection{FMDV Outbreak Characterization and Ag Detection}

During the active disease search (October 2018 to September 2020) of outbreak investigation, a total of 96 herds of cattle were visited and cattle affected clinically with FMD were observed and examined for sampling. The samples collected were gum, tongue epithelial tissue, swabs from lesions as well as oral swab samples. From 96 herds, a total of 72 tissue and swab samples were collected and subjected to rRT-PCR, virus isolations, and antigen ELISA for serotyping. The result showed that in 50 of 72 (69\%) samples (tissue and swab), viral RNA was detected (Ct value less than 32). From these 50 samples, 21 (42\%) produced CPE after 48 hours (after one or two passages). Those who did not produce CPE after two passages were freeze-thawed and another third passage was tried but was not successful. There were also outbreaks where the serotype was not identified due to limited or dead virus material in the sample. Samples with a strong CPE from each cell-cultured isolate 
were subjected to antigen ELISA serotyping. Here mainly, two FMDV serotypes, $\mathrm{O}$ and A, were detected. Among the identified serotypes, six of them were serotyped as serotype A and three of them as serotype O. Serotype A was isolated from samples collected from Guduru, Fitche, and Kuyu, Mukaturi, and Dugda of North and East shoa. On the other hand, serotype $\mathrm{O}$ was detected in three samples from Shashogo, Getawa of South Nation Nationality People, and Ale of Western Oromia (Table 7 and Figure 1).

Table 6. Factors associated with FMD sero-positivity using multivaraible logistic regression analysis in swine $(N=426)$.

\begin{tabular}{|c|c|c|c|c|c|}
\hline Risk Factors & Total Tested Samples & Sero-Positives & Sero-Prevalence $(\%)$ & OR $(95 \%$ CI $)$ & $p$-Value \\
\hline \multicolumn{6}{|l|}{ Districts } \\
\hline Addis Ababa * & 81 & 7 & 8.6 & - & - \\
\hline Alage & 63 & 0 & 0 & & \\
\hline Bishoftu & 282 & 0 & 0 & - & \\
\hline \multicolumn{6}{|l|}{ Sex } \\
\hline Female * & 268 & 5 & 1.8 & - & - \\
\hline Male & 158 & 4 & 2.5 & $1[0.2,4]$ & 0.944 \\
\hline \multicolumn{6}{|l|}{ Age } \\
\hline Young & 247 & 3 & 1.2 & $0.41[0.1,2]$ & 0.229 \\
\hline Adult * & 179 & 6 & 3.3 & - & - \\
\hline \multicolumn{6}{|l|}{ Breed } \\
\hline Large white & 254 & 4 & 1.6 & $0.5[0.1,3]$ & 0.506 \\
\hline Duroc & 101 & 3 & 3.0 & $1[0.14,6]$ & 0.962 \\
\hline Cross * & 71 & 2 & 2.8 & - & - \\
\hline
\end{tabular}

${ }^{*}$ reference category.

Table 7. Diagnostic results of tissue samples from FMD outbreaks in cattle in Ethiopia from September 2018 to September 2019.

\begin{tabular}{|c|c|c|c|c|c|c|}
\hline & & & & $\begin{array}{c}\text { Number } \\
\text { Posi- } \\
\text { tive/Tested }\end{array}$ & & \\
\hline State & Location & Sample Type & \#Herds Affected & rRT-PCR & VI & Serotype in Ag Elisa \\
\hline \multirow[t]{8}{*}{ Oromia } & Kuyu & Epithelial tissue & 11 & $15 / 15$ & 5 & A \\
\hline & Adaa & Epithelial tissue & 11 & $1 / 1$ & 1 & $\mathrm{O}$ \\
\hline & Dugda & Epithelial tissue & 15 & $3 / 3$ & 3 & A \\
\hline & Guduru & Epithelial tissue & 3 & $3 / 3$ & 2 & A \\
\hline & Fitche & Epithelial tissue & 3 & $1 / 1$ & 1 & $\mathrm{~A}$ \\
\hline & Mukaturi & Epithelial tissue & 3 & $1 / 1$ & 1 & $\mathrm{~A}$ \\
\hline & Ale & Epithelial tissue +oral swab & 4 & $4 / 4$ & 2 & $\mathrm{O}$ \\
\hline & Boset & Epithelial tissue & 1 & $1 / 1$ & 0 & ND \\
\hline \multirow[t]{2}{*}{ Amhara } & Gonder zuria & Epithelial tissue & 8 & $6 / 7$ & 0 & ND \\
\hline & Kewet & Epithelial tissue & 9 & $2 / 2$ & 2 & $\mathrm{O}$ \\
\hline \multirow[t]{3}{*}{ Tigray } & Aseged Tsimbela & swab & 1 & $4 / 4$ & 0 & ND \\
\hline & Dejen & Epithelial tissue & 1 & $1 / 1$ & 0 & ND \\
\hline & Wukro & Epithelial tissue & 2 & $2 / 2$ & 0 & ND \\
\hline \multirow[t]{3}{*}{ SNNP } & Getewaa & Epithelial tissue +oral swab & 20 & $2 / 20$ & 2 & $\mathrm{O}$ \\
\hline & Worka & Epithelial tissue +oral swab & 2 & $2 / 2$ & 0 & ND \\
\hline & Shashogo & Epithelial tissue +oral swab & 2 & $2 / 2$ & 2 & $\mathrm{O}$ \\
\hline Total & & & 18 & $50 / 72$ & $21 /$ & \\
\hline
\end{tabular}

ND, not done because of insufficient viral material VI, Virus isolation SNNP, South Nation Nationalities People, rRT-PCR, reverse transcriptase Real Time Polymerase Chain Reaction. 


\subsubsection{Phylogenetic Analysis of FMDV Serotype O}

The complete (639 nucleotides) VP1 sequence was aligned and compared with archived data from across Africa to reconstruct phylogenetic relationships of the isolates with reference VP1 FMD virus sequences from GenBank (https:/ / www.ncbi.nlm.nih.gov/genbank/, accessed on 20 July 2021). Isolate O/ETH/72/2018, from SNNP O/ETH/73/2018, and cattle were compared to serotype O Egyptian isolates of Behira 2/EGY/2017, Alexandria 1/EGY/2017, Giza 1/EGY/2017, Fayoum 3/EGY/2017, and Fayoum 1/EGY/2017. This analysis showed $98 \%$ sequence identity, suggesting the existence of a close genetic relationship. Another isolate from SNNP region O/ETH/14/2019 was seen to have 92\% sequence identity with Kenyan isolate O/KEN/100/2010 and $88 \%$ sequence identity with Ugandan isolate of $\mathrm{O} / \mathrm{UGA} / 9 / 98, \mathrm{O} / \mathrm{U} / 97 / 99, \mathrm{O} / \mathrm{UGA} / 17 / 98$, and O/UGA/10/98, as well as Ethiopian isolates of 2016, 2013, 2005 and Nepal (NEP/121/1990). The genetic relationship among the three isolates was determined by multiple sequence alignment. The isolate of Kaffa, SNNP region O/ETH/72/2018 was 99\% identical to the isolate from Ale, Oromia region O/ETH/73/2018 (EA-3), whereas there was a $22 \%$ nucleotide difference between the Shashogo district of SNNP isolates O/ETH/14/2019 (EA-4) and Ale district of Oromia region $\mathrm{O} / \mathrm{ETH} / 73 / 2018$. The phylogenetic tree for serotype $\mathrm{O}$ is shown in Figure 2.

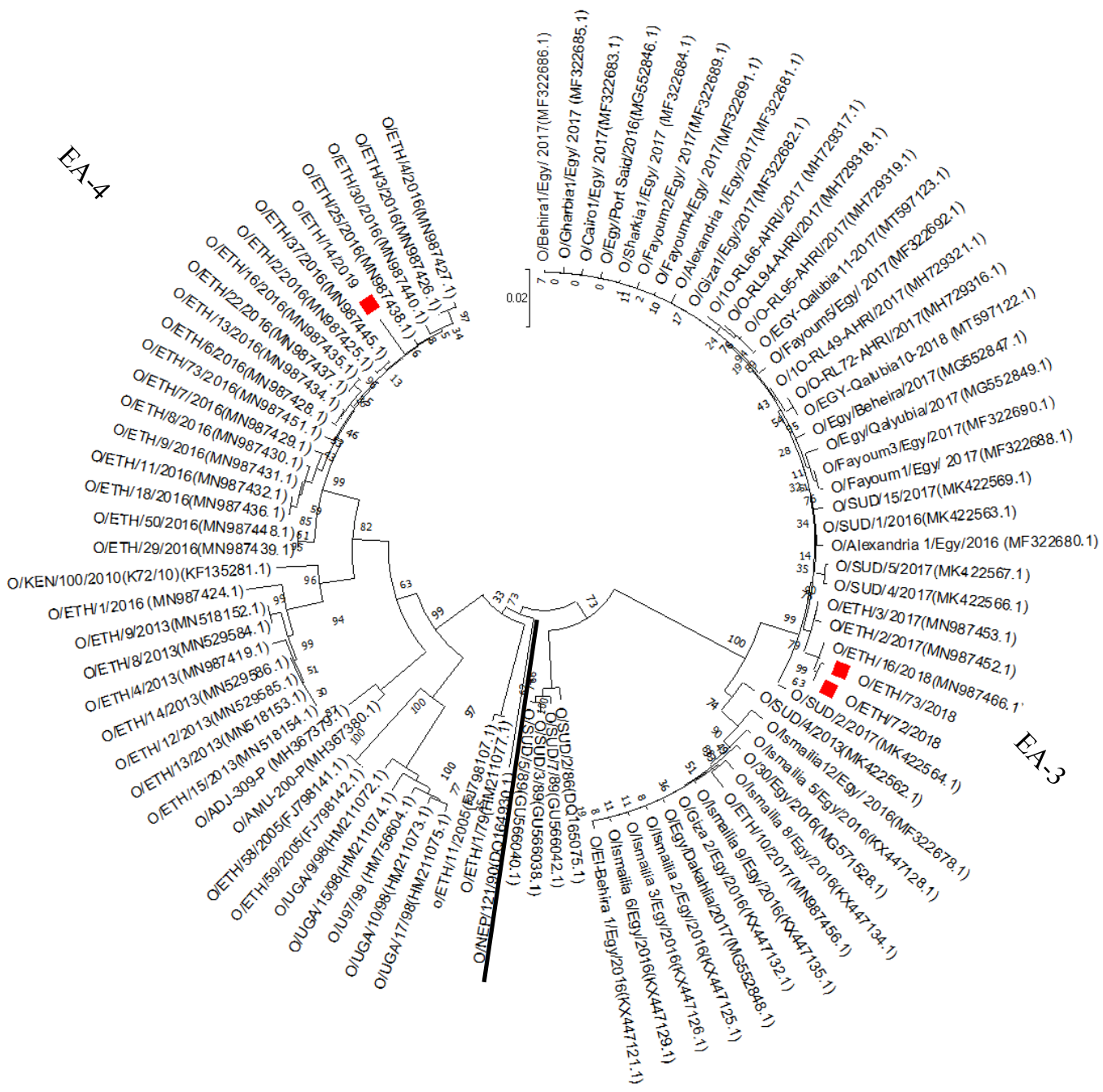

Figure 2. Mid-point-rooted neighbor-joining phylogenetic tree of serotype O FMDV local isolates in comparison with serotype $\mathrm{O}$ isolates from Ethiopia and other referenced counties. New isolates obtained from outbreak cases are indicated by $(\square$ ). 


\subsection{Phylogenetic Analysis of FMDV Serotype A}

In this case, the isolate from cattle of the Kuyu A/ETH/85/2018, Fitche A/ETH/86/2018, and Mukaturi A/ETH/87/2018 Oromia region nucleotide sequences showed more than $92 \%$ sequence identity to the isolates of Eritrea A/ERI/1/2006 and Sudan A/SUD/3/2006 and other Ethiopian isolates of 2018. It was also compared to two isolates of A/ERI/3/98 and $\mathrm{A} / \mathrm{ERI} / 3 / 97$ and showed $87 \%$ sequence identity to the above isolates. This shows that this particular isolate has a genetic relationship with the Eritrean and Sudanese isolates. Other isolates from the Guduru district from cattle A/ETH/16/2019, A/ETH/18/2019, and $\mathrm{A} / \mathrm{ETH} / 19 / 2019$ had $92 \%$ identical sequence with the Eritrea A/ERI/1/2006 and Sudan A/SUD/1/2006, A/SUD/2/2006, A/SUD/3/2006, A/SUD/1/2013, A/SUD/10/2013, A/SUD/12/2013, A/SUD/21/2014, A/SUD/18/2014, A/SUD/10/2018, A/SUD/11/2018, $\mathrm{A} / \mathrm{SUD} / 3 / 2018$, and A/SUD/4/2018 isolates. The genetic relationship among the six isolates was determined by multiple sequence alignment. The Guduru isolates A/ETH/16/2019, A/ETH/18/2019, and (A/ETH/19/2019) had 98\% identity among themselves. These three isolates had $98 \%$ sequence identity with the A/ETH/85/2018, A/ETH/86/2018, and A/ETH/87/2018) sequences of the Guyagusee, Fitche, and Mukaturi isolates. The phylogenetic tree for serotype A is shown in Figure 3.

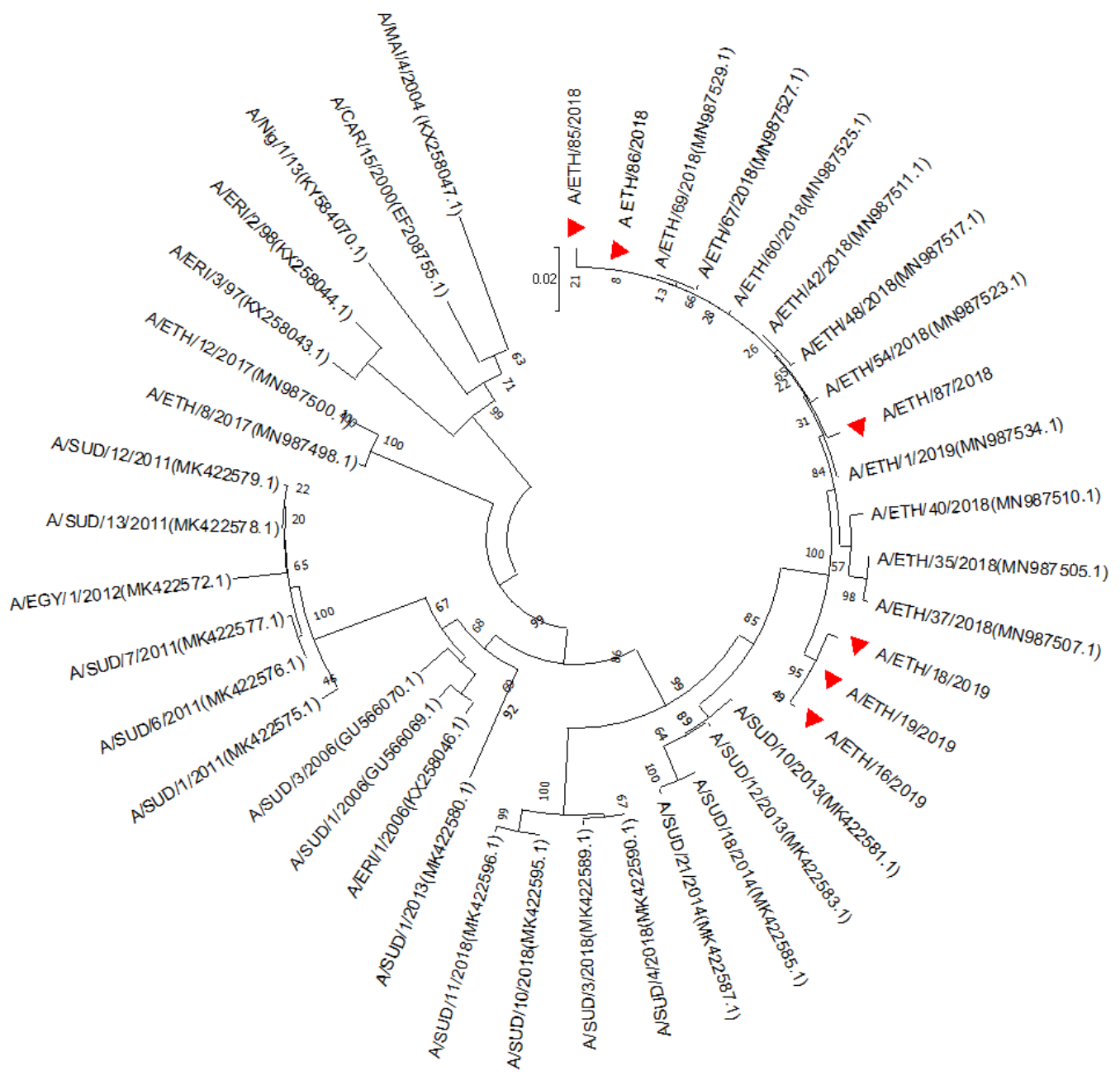

Figure 3. Mid-point-rooted neighbor-joining phylogenetic tree of serotype A FMDV isolates in comparison with serotype A isolates from Ethiopia and other reference countries. New isolates from Guduru, Kuyu, Fitche, and Muketuri of Oromia Region are indicated by $(\nabla)$ topotypes: A/Africa/G-IV. 


\section{Discussion}

FMD is considered to remain endemic with wide occurrence provoking outbreaks every year in Ethiopia as reported by [9]. The situation is further complicated by the fact that the different serotypes and the high contagiousness between animals as well as the viruses are continuously evolving. Information regarding epidemiological understanding is inadequate despite FMDV occurrence. Thus, frequent disease reporting requires monitoring and updated data of the current FMD epidemiological status in the country. This study could certainly have the value to update data on FMD where the epidemiological status of the disease is poorly understood. In this study, an attempt was made to estimate the seroprevalence of FMD in apparently healthy cattle, domestic small ruminants, and swine and to identify risk factors in addition to characterizing the virus at its molecular level.

\subsection{Knowledge, Attitude, and Practice Regarding FMD Outbreak Occurrence, Frequency and its Control Measures}

In this study, KAPS on FMD occurrence and its frequency, husbandry practice, and control strategy applied in their locality was assessed. It was found that frequent occurrence, free type of livestock movement, vehicle and personnel movements in and out, and sharing pasture with swine, small ruminants, herds of different peasant associations and with wildlife were among the practices seen in their location. According to the results of the questionnaire (data not shown), communal grazing places and watering points, different animals in close contact, herding animals close to rivers and flooded areas, presence of nearby market places, and failure to vaccinate animals could be the possible factors that contributed to the high disease transmission and occurrence. This observation was in agreement with observations made by different researchers elsewhere in the world that stated factors such as continuous contact with susceptible animals, the intermingling of different herds $[16,42,43]$, and sharing of grazing area $[31,44]$ and watering points $[45,46]$ with a high number of susceptible animals contribute to the occurrence of FMD outbreak. In Ethiopia in general and in the study areas in particular, there is no official FMD control strategy in place, but the practice of different control and prevention measures were in place before and during the occurrence of the disease. Respondents also mentioned the practice of traditional treatment (with katikala (local liquor), honey, salt, and hot chilies) methods used in the area to dress FMD lesions. This was supported by the finding of [15] from the Amhara region where the same case management system was observed.

\subsection{Seroprevalence and Factors Associated with FMD Sero-Positivity in Cattle}

The present study revealed an ascertained sero-positivity for FMD in five regions of Ethiopia. For this particular study, cattle, swine, and domestic small ruminant commercial farms were used to estimate the presence of antibodies against FMDV NSP in the serum. An overall apparent seroprevalence of 25,2 , and $5 \%$ was recorded in cattle, swine, and small ruminants, respectively. This report signifies the continuous spread of the FMD virus throughout the study areas. This is supported by [37], as sero-positivity is an indication of previous exposure to natural infection. Similar studies conducted at a different times and places documented different levels of prevalence. For cattle, the current finding is comparable to earlier prevalence reports limited to small geographic areas. These reports were $26.5 \%$ from Kellem Wolega, Western, Ethiopia, $24.6 \%$ from Borena pastoral area, Southern Ethiopia, 21.4\% from Borena and Guji, Southern, Ethiopia, and 24.2\% from central, Ethiopia by [12-14,47]. Ehizibolo et al., [48] from Nigeria also reported $(29 \%)$ closely comparable prevalence to ours. The observed high prevalence in the current study could be attributed to the geographical location of the farms, failure to periodically vaccinate animals, improper management practices, herding of farm animals near to wildlife areas, and contact of animals with livestock of other neighborhoods. On the contrary, seroprevalence documented in this survey showed a much higher value as compared to the previous reports of $10.5 \%$ of national prevalence, $9.5 \%$ from southern Ethiopia, $8.18 \%$ from South Omo, Ethiopia, and $14.05 \%$ from Eastern Hararge, Ethiopia by $[9,11,49,50]$, respectively 
On the other hand, a much higher prevalence than the present study was reported, i.e., $42.7 \%$ in Borena, southern Ethiopia by [51], 72.1\% in central Ethiopia [18], and 52.5\% in Kenya by [52] in cattle. These differences could be related to variation in agroecology, geo-spatial distribution of the disease, possible sampling after an outbreak, and variations in the production/herding systems among the areas of the study.

This study showed the level of prevalence of FMD had significant variations between regions; the highest being from the Tigray region (38.68\%) followed by Oromia (26.8\%), Amhara (23.9\%), Addis Ababa (17.7\%), and SNNP (11.2\%) cattle raised for commercial purposes. This difference among regions could be explained by the fact that the variation in a production system, density of livestock in a farm, presence of active outbreak, and variation in agroecology of the areas could result in a significant difference in prevalence.

The age-stratified seroprevalence indicated significantly higher prevalence in adult animals, which is in line with the findings of $[11,13,20,49]$ from Ethiopia and [52] from Kenya. The high seroprevalence in adults in the present study might be attributed to a possibility of a previous infection without being vaccinated/ immunized and/or failure to quarantine infected adult cattle separately. Another possible reason could be that adults are driven freely in grazing and watering points where infection increases by contact with other infected animals. The low seroprevalence in calves and young may be due to the husbandry system that kept them in separation from adults so that exposure to infection would be minimized.

In this study, breed-specific seroprevalence was higher in cross-breed animals (29\%) although the difference in prevalence between breeds was not statistically significant. This is in agreement with the finding of [53], who reported the highest prevalence with crossbreeds. In contrast, [54] reported that breed was associated with FMD outbreaks, with local breeds being the most affected.

\subsection{Sero-Prevalence of FMD in Swine}

The $2 \%$ seroprevalence observed in swine was comparable with reports from subSaharan Africa by Ehizibolo et al. [48], which indicated 1.5\% prevalence. However, the observed result was much lower than reports of Faki et al., [55] from Nigeria, i.e., 18\% prevalence.. The variation in prevalence could be due to the difference in the level of farm intensification, biosecurity levels being used, geographical areas, and location of the swine farms.

\subsection{SeroPrevalence of FMD in Domestic Small Ruminants}

In domestic small ruminants $5 \%$ sero-positivity was recorded. This was in agreement with the findings of [15] (11\%) and is comparable to [16] (4\%). Combined these findings indicate the lower prevalence of FMD in domestic small ruminants. Risk factors, such as the age group of the animals, was significantly associated with FMD sero-positivity ata $p<0.05$. This finding indicates that though the prevalence was lower, it is epidemiologically important as FMDV in small ruminants is subclinical in most cases and can spread over a long distance.

\subsection{Phylogenic Analysis}

The present study described the genetic characterization of two FMDV serotypes (A and O) that were responsible for the outbreaks in the study areas in 2018/19. This is in agreement with various reports from the different corners of the country in different years by $[16,19,20]$. Phylogenetic analysis conducted using the VP1 region sequence showed that serotype O isolates match into the topotype of East Africa (EA-3 EA-4), while serotype A was grouped as an African topotype (A/Africa/G-IV). This findings confirms and support the previously published reports of $[19,21]$, who documented the existence and circulation of EA-3, EA-4, and African topotype of genotype IV in Ethiopia. Recently [56], it was also documented that EA-3 is the predominant topotype which continued circulation was responsible for several outbreaks each year. 


\section{Conclusions and Recommendations}

In the present study, the result of $3 A B C$ ELISA showed an overall anti-FMD antibody prevalence of $25 \%$ in cattle, $5 \%$ in domestic small ruminants, and $2 \%$ in swine.

Additionally, factors such as proximity to other commercial farms, presence of nearby livestock markets, sharing communal pastures and water points, sharing animals, personnel, and vehicles moving in and out of the farm were found to contribute to the occurrence of FMD outbreak. Case management (traditional and antibiotic treatment) was the chief management measure applied in the study areas, with very few practicing vaccinations together with movement restriction. The disease was seen as highly prevalent in cattle. Domestic small ruminants (showing few clinical symptoms and that can spread FMDV over a long distance) and swine (acting as a source for a new outbreak for ruminants) were also seen to have a significant number of sero-reactive animals. The presence of antibodies against FMDV NSP implied exposure to active or previous viral infection. The circulating topotypes were characterized and were found to have nucleotide sequence identity, with previous Ethiopian isolates and isolates from neighboring countries, Sudan, Kenya, Uganda, Eritrean Egypt, and other countries' topotypes. Thus, this study ascertained the lack of disease outbreaks reporting poor husbandry practices, the prevalence of FMD in three domestic species (cattle, small ruminant, and swine), and continuous circulation of serotype A and O in Ethiopia. Generally, this indicates that FMDV endemic countries, as well as free countries, are always at risk for the (re)introduction of (new) FMDV variants. Effective veterinary services complying with OIE standards, veterinary legislation, as well as a public-private partnership as good governance of the animal health system should be practiced in controlling this disease. As control of FMDV at its source is of common interest, global support is very important for countries such as Ethiopia. Hence, in reference to the concluding remarks, the following recommendations are pointed out:

i. Farmers and livestock owners should be trained on the disease, husbandry practices, and how to report FMD outbreaks.

ii. Effective surveillance systems should be implemented for timely information about the occurrence, spread, and causative serotype identification.

iii. Various research and epidemiological studies are needed to investigate the existence of an association between wildlife-swine-cattle interactions.

Supplementary Materials: The following supporting information can be downloaded at: https: //www.mdpi.com/article/10.3390/agriculture12010049/s1.

Author Contributions: F.T.W.: conceived and designed the study, collected and analyzed the data and wrote the manuscript, N.H., collected part of the data, D.L., K.D.C., A.D.V.: conceived and designed the study, revised the manuscript, A.M., D.G., S.T., analyzed the data, J.P. conceived and designed the study, wrote the manuscript; overall supervisor of the project. All authors have read and agreed to the published version of the manuscript.

Funding: This study was financially supported by the Global minds PhD scholarship KU Leuven, Belgium (project number: 4520196970).

Institutional Review Board Statement: Ethical clearance regarding animal handling, sample collection and preservation was obtained from animal research ethical review committee of Addis Ababa University, College of veterinary medicine (Ref. number VM/ERC/03/12/2016).

Informed Consent Statement: Information from the farmers and veterinarian interviewed here is based on oral informed consent.

Data Availability Statement: The data presented in this study are available on request from the corresponding author. The data are publicly available.

Acknowledgments: We would like to thank KU LEUVEN Belgium (HPI), NAHDIC (Ethiopia), Sciensano (Belgium), and AAU, Ethiopia. 
Conflicts of Interest: The authors declare no conflict of interest. The funders had no role in the design of the study; in the collection, analyses, or interpretation of data; in the writing of the manuscript, or in the decision to publish the results.

\section{References}

1. Alexandersen, S.; Mowat, N. Foot-and-mouth disease: Host range and pathogenesis. Curr. Top. Microbiol. Immunol. 2005, 288, 9-42. [CrossRef]

2. Arzt, J.; Baxt, B.; Grubman, M.J.; Jackson, T.; Juleff, N.; Rhyan, J.; Rieder, E.; Waters, R.; Rodriguez, L.L. The pathogenesis of foot-and-mouth disease II: Viral pathways in swine, small ruminants, and wildlife; myotropism, chronic syndromes, and molecular virus-host interactions. Transbound. Emerg. Dis. 2011, 58, 305-326. [CrossRef] [PubMed]

3. Arzt, J.; Juleff, N.; Zhang, Z.; Rodriguez, L.L. The pathogenesis of foot-and-mouth disease I: Viral pathways in cattle. Transbound. Emerg. Dis. 2011, 58, 291-304. [CrossRef] [PubMed]

4. Zell, R.; Delwart, E.; Gorbalenya, A.; Hovi, T.; King, A.M.Q.; Knowles, N.J.; Lindberg, A.M.; Pallansch, M.A.; Palmenberg, A.C.; Reuter, G.; et al. ICTV Virus Taxonomy Profile: Picornaviridae. J. Gen. Virol. 2017, 98, 2421-2422. [CrossRef]

5. Paton, D.J.; Valarcher, J.F.; Bergmann, I.; Matlho, O.G.; Zakharov, V.M.; Palma, E.L.; Thomson, G.R. Selection of foot and mouth disease vaccine strains: A review. Rev. Sci. Tech. 2005, 24,981-993. Available online: https://pubmed.ncbi.nlm.nih.gov/16642769/ (accessed on 15 June 2021). [CrossRef] [PubMed]

6. Waters, R.; Ludi, A.B.; Fowler, V.L.; Wilsden, G.; Browning, C.; Gubbins, S.; Statham, B.; Bin-Tarif, A.; Mioulet, V.; King, D.J.; et al Efficacy of a high-potency multivalent foot-and-mouth disease virus vaccine in cattle against heterologous challenge with a field virus from the emerging A/ASIA/G-VII lineage. Vaccine 2018, 36, 1901-1907. [CrossRef]

7. Martel, J.L. Foot-and-mouth disease in Ethiopia. Distribution of serotypes of foot-and-mouth disease virus. Rev. Elev. Med. Vet. Pays Trop. 1974, 27, 169-175. [CrossRef]

8. Shiferaw, T.J.; Moses, K.; Manyahilishal, K.E. Participatory appraisal of foot and mouth disease in the Afar pastoral area, northeast Ethiopia: Implications for understanding disease ecology and control strategy. Trop. Anim. Health Prod. 2010, 42, 193-201. [CrossRef]

9. Ayelet, G.; Gelaye, E.; Negussie, H.; Asmare, K. Study on the epidemiology of foot and mouth disease in Ethiopia. Rev. Sci. Tech. 2012, 31, 789-798. [CrossRef] [PubMed]

10. Bayissa, B.; Ayelet, G.; Kyule, M.; Jibril, Y.; Gelaye, E. Study on seroprevalence, risk factors, and economic impact of foot-andmouth disease in Borena pastoral and agro-pastoral system, southern Ethiopia. Trop. Anim. Health Prod. 2011, 43, 759-766. [CrossRef] [PubMed]

11. Megersa, B.; Abuna, F.; Amanu, K.; Rufael, T. Risk factors for foot and mouth disease seroprevalence in indigenous cattle in Southern Ethiopia: The effect of production system. Trop. Anim. Health Prod. 2008, 41, 891-898. [CrossRef] [PubMed]

12. Mekonen, H.; Beyene, D.; Rufael, T.; Feyisa, A.; Abunna, F. Study on the prevalence of Foot and Mouth Disease in Borana and Guji Zones, southern Ethiopia Study on the prevalence of Foot and Mouth Disease in Borana. Veter. World 2011, 4, 293-296. [CrossRef]

13. Rufael, T.; Catley, A.; Bogale, A.; Sahle, M.; Shiferaw, Y. Foot and mouth disease in the Borana pastoral system, southern Ethiopia and implications for livelihoods and international trade. Trop. Anim. Health Prod. 2007, 40, 29-38. [CrossRef] [PubMed]

14. Sulayeman, M.; Dawo, F.; Mammo, B.; Gizaw, D.; Shegu, D. Isolation, molecular characterization and sero-prevalence study of foot-and-mouth disease virus circulating in central Ethiopia. BMC Veter. Res. 2018, 14, 110. [CrossRef] [PubMed]

15. Mesfine, M.; Nigatu, S.; Belayneh, N.; Jemberu, W.T. Sero-Epidemiology of Foot and Mouth Disease in Domestic Ruminants in Amhara Region. Front. Veter. Sci. 2019, 6, 130. [CrossRef]

16. Sahle, M.; Venter, E.H.; Dwarka, R.M.; Vosloo, W. Molecular epidemiology of serotype O foot-and-mouth disease virus isolated from cattle in Ethiopia between 1979-2001. Onderstepoort J. Veter. Res. 2004, 71, 129-138. [CrossRef]

17. Beyene, B.; Tolosa, T.; Rufael, T.; Hailu, B.; Teklue, T. Foot and mouth disease in selected districts of western Ethiopia: Seroprevalence and associated risk factors. Rev. Sci. Tech. 2015, 34, 939-952. [CrossRef] [PubMed]

18. Awel, S.M.; Dilba, G.M.; Abraha, B.; Zewde, D.; Wakjira, B.S.; Aliy, A. Seroprevalence and Molecular Detection of Foot and Mouth Disease Virus in Dairy Cattle Around Addis Ababa, Central Ethiopia. Veter. Med. Res. Rep. 2021, 12, 187-197. [CrossRef] [PubMed]

19. Ayelet, G.; Mahapatra, M.; Gelaye, E.; Egziabher, B.G.; Rufeal, T.; Sahle, M.; Ferris, N.P.; Wadsworth, J.; Hutchings, G.H.; Knowles, N.J. Genetic characterization of foot-and-mouth disease viruses, Ethiopia, 1981-2007. Emerg. Infect. Dis. 2009, 15, 1409-1417. [CrossRef]

20. Negusssie, H.; Kyule, M.N.; Yami, M. Outbreak investigations and genetic characterization of foot-and-mouth disease virus in Ethiopia in 2008/2009. Trop. Anim. Health Prod. 2010, 43, 235-243. [CrossRef]

21. Gizaw, D.; Tesfaye, Y.; Wood, B.A.; Di Nardo, A.; Shegu, D.; Muluneh, A.; Bilata, T.; Belayneh, R.; Fentie, A.; Asgdome, H.; et al. Molecular characterization of foot-and-mouth disease viruses circulating in Ethiopia between 2008 and 2019. Transbound. Emerg. Dis. 2020, 67, 2983-2992. [CrossRef] [PubMed]

22. Tesfaye, Y.; Khan, F.; Gelaye, E. Molecular characterization of foot-and-mouth disease viruses collected from Northern and Central Ethiopia during the 2018 outbreak. Veter. World 2020, 13, 542-548. [CrossRef]

23. Food and Agriculture Organization of the United Nations. Livestock Production Systems Spotlight Ethiopia. FAO, Rome, Italy. 2018. Available online: https:/ / www.fao.org/publications/card/en/c/I8271EN/ (accessed on 15 May 2021). 
24. MoARD. Livestock Development Master Plan Study; Phase I Report—Data Collection and Analysis. Volume B-Meat Production November 2007; Ministry of Agriculture and Rural Development, Government of Ethiopia: Addis Ababa, Ethiopia, 2007; Volume B.

25. Jenbere, T.; Etana, M.; Negussie, H. Study on the risk factors of foot and mouth disease in selected districts of Afar Pastoral Area, Northeast Ethiopia. J. Anim. Veter. Adv. 2011, 10, 1368-1372. [CrossRef]

26. Leta, S.; Mesele, F. Spatial analysis of cattle and shoat population in Ethiopia: Growth trend, distribution and market access. SpringerPlus 2014, 3, 310. Available online: https:/ / springerplus.springeropen.com/articles/10.1186/2193-1801-3-310 (accessed on 19 June 2021). [CrossRef]

27. CSA. The Federal Democratic Republic of Ethiopia Central Statistical Agency Volume Vii Report on Crop and Livestock Product Utilization (Private Peasant Holdings, Meher Season). Stat Bull. E VII: 577. 2012. Available online: http//www.csa.gov.et (accessed on 10 May 2021).

28. CSA. The Federal Democratic Republic of Ethiopia Central Statistical Agency Agricultural Sample Survey 2016/2017 (2009 E.C). Volume I Report on Area and Production of Major Crops (Private Peasant Holdings, Meherseason), AddisAbaba. Available online: http/ / www.csa.gov.et (accessed on 15 May 2021).

29. Muroga, N.; Kobayashi, S.; Nishida, T.; Hayama, Y.; Kawano, T.; Yamamoto, T.; Tsutsui, T. Risk factors for the transmission of foot-and-mouth disease during the 2010 outbreak in Japan: A case-control study. BMC Veter. Res. 2013, 9, 150. [CrossRef]

30. Wee, S.-H.; Yoon, H.; More, S.; Nam, H.-M.; Moon, O.-K.; Jung, J.-M.; Kim, S.-J.; Kim, C.-H.; Lee, E.-S.; Park, C.-K.; et al. Epidemiological characteristics of the 2002 outbreak of foot-and-mouth disease in the Republic of Korea. Transbound. Emerg. Dis. 2008, 55, 360-368. [CrossRef]

31. Dukpa, K.; Robertson, I.; Edwards, J.R.; Ellis, T.M.; Tshering, P.; Rinzin, K.; Dahal, N. Risk factors for foot-and-mouth disease in sedentary livestock herds in selected villages in four regions of Bhutan. N. Z. Veter. J. 2011, 59, 51-58. [CrossRef] [PubMed]

32. Jamal, S.M.; Belsham, G.J. Foot-and-mouth disease: Past, present and future. Veter. Res. 2013, 44, 116. [CrossRef] [PubMed]

33. Hegde, R.; Gomes, A.R.; Giridhar, P.; Kowalli, S.; Shivashankar, B.P.; Sudharshana, K.J.; Nagaraj, K.; Sesharao, R.; Mallinath, K.C.; Shankar, B.P.; et al. Epidemiology of foot and mouth disease in Karnataka state, India: A retrospective study. VirusDisease 2014, 25, 504-509. [CrossRef]

34. Bastos, A.D.S.; Boshoff, C.I.; Keet, D.F.; Bengis, R.G.; Thomson, G.R. Natural Transmission of Foot-and-Mouth Disease Virus between African buffalo (Syncerus caffer) and Impala (Aepyceros melampus) in the Kruger National Park, South Africa. Epidemiol. Infect. 2000, 124, 591-598. [CrossRef] [PubMed]

35. Humphry, R.W.; Cameron, A.; Gunn, G.J. A practical approach to calculate sample size for herd prevalence surveys. Prev. Veter. Med. 2004, 65, 173-188. [CrossRef]

36. Nicholson, M.; Butterworth, H. A guide to condition scoring of Zebu cattle, Addis Ababa Ethiopia. Int. Livest. Cent. Afr. 1986, 29, 212-225.

37. OIE. Manual of Diagnostic Tests and Vaccines for Terrestrial Animals; Collect, Submiss Storage Diagnostic Specimens; OIE: Paris, France, 2009.

38. Callahan, J.D.; Brown, F.; Osorio, F.A.; Sur, J.-H.; Kramer, E.; Long, G.W.; Lubroth, J.; Ellis, S.J.; Shoulars, K.S.; Gaffney, K.L.; et al. Use of a portable real-time reverse transcriptase-polymerase chain reaction assay for rapid detection of foot-and-mouth disease virus. J. Am. Veter. Med. Assoc. 2002, 220, 1636-1642. [CrossRef] [PubMed]

39. Tamura, K.; Stecher, G.; Peterson, D.; Filipski, A.; Kumar, S. MEGA6: Molecular Evolutionary Genetics Analysis version 6.0. Mol. Biol. Evol. 2013, 30, 2725-2729. [CrossRef] [PubMed]

40. StataCorp. Stata Statistical Software: Release 14. College Station, TX: StataCorp LP. 2015. Available online: https: //www.google.com/search?q=StataCorp.+2015.+Stata+Statistical+Software\%3A+Release+14.+College+Station\%2C+TX\%3A+ StataCorp+LP.\&source=hp\&ei=uwFwYMuSGtGJlwT2066wBQ\&iflsig (accessed on 12 March 2021).

41. QGIS Developement Team. QGIS Geographic Information System. Open Source Geospatial Foundation. 2009. Available online: http:/ / qgis.osgeo.org (accessed on 15 March 2021).

42. Sutmoller, P.; Casas, O.R. Unapparent foot and mouth disease infection (sub-clinical infections and carriers): Implications for control. Rev. Sci. Tech. 2002, 21, 519-529. [CrossRef] [PubMed]

43. Abbas, T.; Younus, M.; Muhmmad, S.A.; Ijaz, M.; Shakoor, A. Some challenges to progressive control of foot and mouth disease in Pakistan-Findings of a pilot survey. Transbound. Emerg. Dis. 2012, 61, 81-85. [CrossRef] [PubMed]

44. Admassu, B. Report on the Participatory Epidemiological Investigation of FMD in Erzurum Province; Food and Agriculture Organization: Rome, Italy, 2005.

45. Ghoneim, N.H.; Abdel-Karim, A.-K.M.; El-Shehawy, L.; Abdel-Moein, K.A. Foot and mouth disease in animals in Sharkia governorate-Egypt. Transbound. Emerg. Dis. 2010, 57, 19-21. [CrossRef]

46. Bronsvoort, B.D.C.; Nfon, C.; Hamman, S.; Tanya, V.; Kitching, R.; Morgan, K. Risk factors for herdsman-reported foot-and-mouth disease in the Adamawa Province of Cameroon. Prev. Veter. Med. 2004, 66, 127-139. [CrossRef] [PubMed]

47. Desissa, F.; Tura, D.; Mamo, B.; Rufael, T. Epidemiological study on foot and mouth disease in cattle: Seroprevalence and risk factor assessment in kellem wollega, western Ethiopia. Afr. J. Agric. Res. 2014, 9, 1391-1395. [CrossRef]

48. Ehizibolo, D.O.; Perez, A.M.; Carrillo, C.; Pauszek, S.; AlKhamis, M.; Ajogi, I.; Umoh, J.U.; Kazeem, H.M.; Fabian, A.; Berninger, M.; et al. Epidemiological analysis, serological prevalence and genotypic analysis of foot-and-mouth disease in Nigeria 2008-2009. Transbound. Emerg. Dis. 2014, 61, 500-510. [CrossRef] 
49. Molla, B.; Ayelet, G.; Asfaw, Y.; Jibril, Y.; Ganga, G.; Gelaye, E. Epidemiological study on foot-and-mouth disease in cattle: Seroprevalence and risk factor assessment in South Omo zone, south-western Ethiopia. Transbound. Emerg. Dis. 2010, 57, 340-347. [CrossRef] [PubMed]

50. Mohamoud, A.; Tessema, E.; Degefu, H. Seroprevalence of bovine foot and mouth disease (FMD) in Awbere and Babille districts of Jijiga zone, Somalia Regional State, Eastern Ethiopia. Afr. J. Microbiol. Res. 2011, 5, 3559-3563. [CrossRef]

51. Melkamsew, A.T. Sero-prevalence of foot and mouth disease in cattle in Borena Zone, Oromia regional state, Ethiopia ISDS 2018 Conference Abstracts. ISDS Annu. Conf. Proc. 2018, 10, 2-3.

52. Kibore, B.; Gitao, C.G.; Sangula, A.; Kitala, P. Foot and mouth disease sero-prevalence in cattle in Kenya. J. Vet. Med. Anim. Health 2013, 5, 262-268. [CrossRef]

53. Duguma, M.; Jibril, Y.; Issa, A.; Hunde, A. Sero-Prevalence of Foot and Mouth Disease of Cattle in Bale Zone, Oromiya Regional State, Ethiopia. Glob. Vet. 2013, 11, 59-64. [CrossRef]

54. Knowles, N.J.; Samuel, A.R. Molecular epidemiology of foot-and-mouth disease virus. Virus Res. 2003, 91, 65-80. [CrossRef]

55. Fakai, L.; Faleke, O.; Magaji, A.; Ibitoye, E.; Alkali, B. Seroprevalence of foot and mouth disease virus infection in pigs from Zuru, Nigeria. Veter. World 2015, 8, 865-869. [CrossRef]

56. Lloyd-Jones, K.; Mahapatra, M.; Upadhyaya, S.; Paton, D.J.; Babu, A.; Hutchings, G.; Parida, S. Genetic and antigenic characterization of serotype O FMD viruses from East Africa for the selection of suitable vaccine strain. Vaccine 2017, 35, 6842-6849. [CrossRef] 